\title{
ANOTASI BIBLIOGRAFI \\ PENGUNAAN APLIKASI ZOOM, CLASSROOM, WHATSAAP DALAM \\ PEMBELAJARAN SEJARAH
}

\author{
Ari Sandi \\ 1710111310003 \\ Program Studi Pendidikan Sejarah Fakultas Keguruan dan Ilmu Pendidikan \\ Universitas Lambung Mangkurat \\ Banjarmasin
}

Susanto, H., \& Akmal, H. (2018). Efektivitas Penggunaan aplikasi pembelajaran berbasis mobile smartphone sebagai media pengenalan sejarah lokal masa revolusi fisik di kalimantan selatan pada siswa sekolah menengah atas. Historia Jurnal, volume 6(2).

Penelitian ini bertujuan untuk mengetahui keefektifan aplikasi pembelajaran yang diakses melalui mobile smartphone sebagai media pengenalan sejarah lokal masa revolusi fisik di Kalimantan Selatan. Subjek penelitian adalah siswa kelas XI IPS SMAN 7Banjarmasin yang terdiri dari dua kelas dengan jumlah populasi sebanyak 57 orang.

Susanto, H. (2019). Media Pembelajaran Sejarah Era Teknologi Informasi (Konsep Dasar, Prinsip Aplikatif, dan Perancangannya). FKIP Universitas Lambung Mangkurat

Perkembangan teknologi informasi membawa dampak yang sangat luas dalam kehidupan kita sehari-hari, tidak terkecuali dalam pembelajaran sejarah.Satu diantaranta dari perkembangan teknologi informasi tersebut adalah penggunaan media berbasis daring dalam pembelajaran sejarah. media pembelajaran sejarah berbasis teknologi informasi, dan bagaimana merancang media pembelajaran sejarah berbasis teknologi informas.

Susanto, H. (2019)Pengunaan Teknologi Sebagai Media Pembelajaran Ips di Masa Pandemi Covid-19. FKIP Universitas Lambung Mangkurat.

Di era sekarang ini pendidikan dan pembelajaran bisa dilakukan di mana saja, apalagi pada saat ini semua Negara sedang dilanda pandemic covid-19 ( 
Corona Virus Disease ). Kegiatan belajar mengajar secara tatap mukapun terganggu, oleh karena itu untuk sekarang ini kegitan belajar mengajar dapat dilakukan secara daring atau online tidak harus dilakukan di ruang kelas, akan tetapi bisa dilakukan di tempat mana saja dan waktu kapan saja. Dalam pendidikan banyak sekali yang dapat kita jadikan sebagai sumber belajar, tidak hanya buku saja melainkan bisa juga dengan menggunakan lingkungan sekitar kita, selain lingkungan kita juga bisa menggunakan media digital sebagai sumber belajar kita agar lebih mudah di era pandemi ini. Seperti pembelajaran daring yang menggunakan smartphone yang dilengkapi fitur zoom, google meet dan lain sebagainya.

\section{Simpulan Konseptual Anotasi Bibliografi}

Penelitian ini bertujuan untuk mengetahui keefektifan aplikasi pembelajaran yang diakses melalui mobile smartphone sebagai media pengenalan sejarah lokal masa revolusi fisik di Kalimantan Selatan. Perkembangan teknologi informasi membawa dampak yang sangat luas dalam kehidupan kita sehari-hari, tidak terkecuali dalam pembelajaran sejarah.Satu diantaranta dari perkembangan teknologi informasi tersebut adalah penggunaan media berbasis daring dalam pembelajaran sejarah. Dalam pendidikan banyak sekali yang dapat kita jadikan sebagai sumber belajar, tidak hanya buku saja melainkan bisa juga dengan menggunakan lingkungan sekitar kita, selain lingkungan kita juga bisa menggunakan media digital sebagai sumber belajar kita agar lebih mudah di era pandemi ini. 